Journal of Advanced Research in Fluid Mechanics and Thermal Sciences

Journal homepage: www.akademiabaru.com/arfmts.html ISSN: 2289-7879

\title{
Potential of Natural Ventilation in Different Algerian Climates
}

\author{
Meriem Mezouari ${ }^{1,}{ }^{*}$, Naima Fezzioui ${ }^{1}$, Mohamed El-mir ${ }^{2}$, Roulet Claude-Alain ${ }^{3}$ \\ Laboratoire de mécaniques de structures, LMS, Université de Béchar, Algérie \\ Laboratoire d'énergie dans les zones arides ENERGARID, Université de Bechar, Algérie \\ École Polytechnique Fédérale de Lausanne EPFL, France
}

\section{ARTICLE INFO
ABSTRACT}

\section{Article history:}

Received 11 May 2020

Received in revised form 4 August 2020

Accepted 7 August 2020

Available online 14 November 2020

\section{Keywords:}

Algerian climate; natural ventilation;

thermal comfort; TRNSYS-COMIS

\begin{abstract}
This study tested the effectiveness of some natural ventilation basic configurations for the thermal comfort of occupants in different local climates in Algeria. Due to the diverse Algerian climate, the study was performed during the mid-season period that includes three months of May, September, and October and the summer that includes the months of June, July, and August. The ventilation potential of the selected configurations was analysed through numerical simulation by using TRNSYS software coupled with COMIS aeraulic software. The results showed the significant contribution of natural chimney ventilation caused by a stairwell to improve occupant comfort. However; its integration requires a judicious and permanent inspection to control temperature decreases or overheating risks.
\end{abstract}

\section{Introduction}

The building sector is the largest consumer of energy; in the building sector, energy required for heating, ventilation, and air-conditioning (HVAC) systems accounts for almost $60 \%$ of global energy consumption [1].

Energy demands for buildings are growing steadily and may exceed $64 \%$ of global energy consumption by 2100 [2]. The energy used for cooling plays a crucial role in an energy balance, especially in the Mediterranean climate, due to the increasing use of mechanical conditioning devices [3] caused by climate changes and global warming [4]. Moreover, emphasizing that concrete is the most used material in building construction worldwide is necessary. The night time is inadequate to dissipate the thermal energy absorbed on hot days. Furthermore, air conditioning is necessary to keep people comfortable and therefore leads to the increase in energy costs [5].

To overcome this problem, several authors have investigated passive cooling techniques, which can be used to reduce energy consumption and to achieve an acceptable level of thermal comfort. However, thermal comfort is subjective and difficult to evaluate, but temperature, airflow speed, and

\footnotetext{
* Corresponding author.

E-mail address: meriem.m82@live.fr
} 
relative humidity can be measured and controlled [6]. Among these techniques, natural ventilation is widely studied numerically by using computational fluid dynamics (CFD). A study [7] examined natural ventilation for underground constructions in Spain, while another study [8] used a methodology and a case study for optimizing the natural ventilation of buildings by simulating the CFD wind environment in three different aspects, namely site planning, building shape, and building envelope. This study was conducted to propose ideas to remedy the inadequacy and weak synergy between the architectural design and technological analysis. Moreover, a study [9] used an unstable RNG k- $\varepsilon$ model to determine the air flow around and inside buildings. A study [10] investigated the potential of natural ventilation in a traditional Iranian CFD strategy, and reference [11] assessed the air flow in a traditional building fitted with a bilateral wind catcher by using a standard turbulence model $(k-\varepsilon)$.

Moreover, ventilation plays a role in preserving the durability of building structures. The condensation rate during winter in certain buildings contributes to the creation of building pathologies that causes structure degradation $[12,13]$. Furthermore, studies have shown that natural ventilation inside an enclosed space in a humid climate is beneficial for three reasons: promotion of thermal comfort, air purification inside buildings, and lower energy consumption [10]. In addition, natural ventilation reduces carbon emission [14] and increases energy costs by $40 \%$ compared with air-conditioned buildings [15]. Algeria is no exception. Algerian climate requires air conditioning even in mid-seasons because of the hot and dry climate and during summers because of the continental climate; at highlands, inhabitants are forced to use air conditioners, as indicated on the scale sheet of SONELGAZ (national electricity and gas company).

Several studies have been conducted in Algeria on natural ventilation. Air circulation has been analyzed, and it strongly depends on openings (windows, doors, and orifices), their dimensions, and their locations in rooms $[16,17]$. Moreover, a study [18] investigated the effect of natural night ventilation by using numerical analysis during summers in the hot and a dry climate in east Algeria, by coupling between TRNSYS and CONTAM. Their results showed the apparent effect of window dimensions on ventilation improvement.

This study evaluated the contribution of natural ventilation to improve thermal comfort obtained from simple and transversal ventilation and from thermal draft by using large upper openings. TRNSYS and COMIS software were coupled to estimate interior temperature for different zones and each basic configuration by using numerical simulations. The study was performed in different weather conditions in Algeria: Mediterranean, Semi-arid cold, desert, and very hot desert climates.

\section{Description of Different Climates}

The climate highly affects the thermal comfort and energy consumption of buildings. Energy codes and standards are based on a clear definition of climate zones to meet manufacturer requirements. Algeria, which covers an area of 2,381,741 km², has undergone three climatic zoning classifications: in 1962, 1984, and 2015. The latter was developed in the study [19] and was based on the analysis of climate data recorded by 60 weather stations during 1999-2008 by defining climate zoning maps according to thermal energy costs required for heating and cooling.

Heating costs less in Algeria than air conditioning does, which is achieved by using electricity, the authors provided two maps (Figure 1) of the climatic zones of Algeria for: heating (A) and cooling (B). Another map of climatic zones based on energy consumption costs was drawn. The energyconsumption-cost-based map was used to select the cities for the study (Figure 5). 

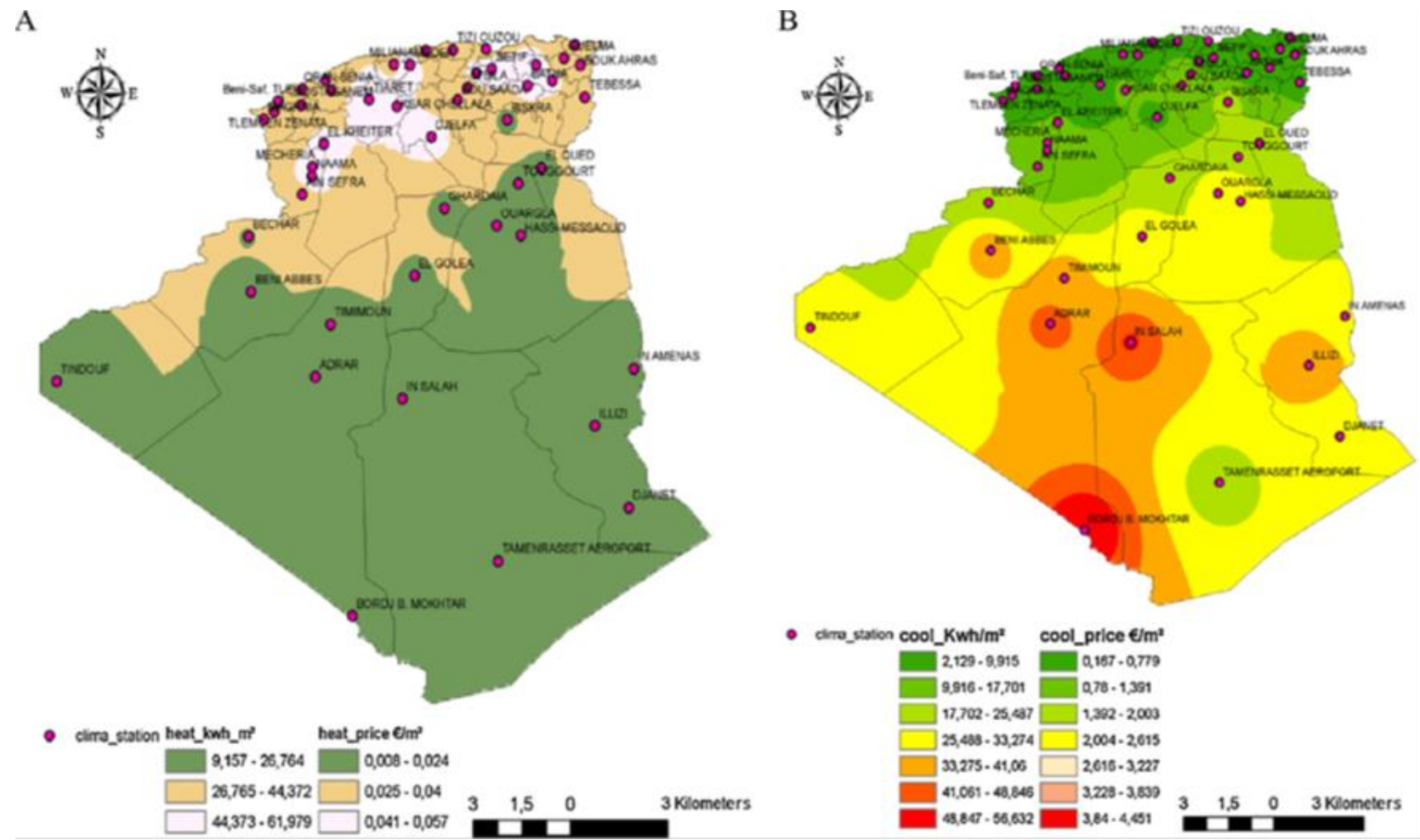

Fig. 1. Map of the climatic zones of Algeria: (A) heating; (B) cooling [19]

Several studies have shown that the aridity of the Saharan climate requires the use of air conditioners in summers $[20,21]$ and for achieving optimal comfort during this period, a combination of several passive cooling strategies is necessary.

According to the psychometric diagram for the climate of Hassi Messaoud (Figure 2), the hottest and driest months are 2/3 of May and June-September; solar control, thermal mass effect (thermal inertia), and evaporative cooling and night ventilation are the strategies recommended for this period to reintegrate summer comfort [22].

According to the psychometric diagram of the climate of Bechar (Figure 3), thermal mass and natural ventilation can provide an acceptable level of comfort when heat is bearable during May and September.

According to Szokoly's diagram, natural ventilation is not adequate during summers in hot and dry climates (Figure 4). However, for the Mediterranean climate, night ventilation highly contributes to improving comfort in summers. Therefore, for the selected climates representing each climate zone, we tested the ventilation potential during summers for coastal cities in the north of the country and highlands. For the cities of the south of the country, we limited our study to a midseason period.

To properly conduct our study, we selected seven climatic zones of Algeria according to new climate zoning (Figure 5): Bechar: desert climate (light green); Adrar: substantially hot desert climate (orange); Illizi: hot desert climate (peach); Ouargla: hot desert climate (yellow); In-salah: very hot desert climate (red); Oran: mild Mediterranean climate (dark green); and Djelfa: Semi-arid cold climate (green). 


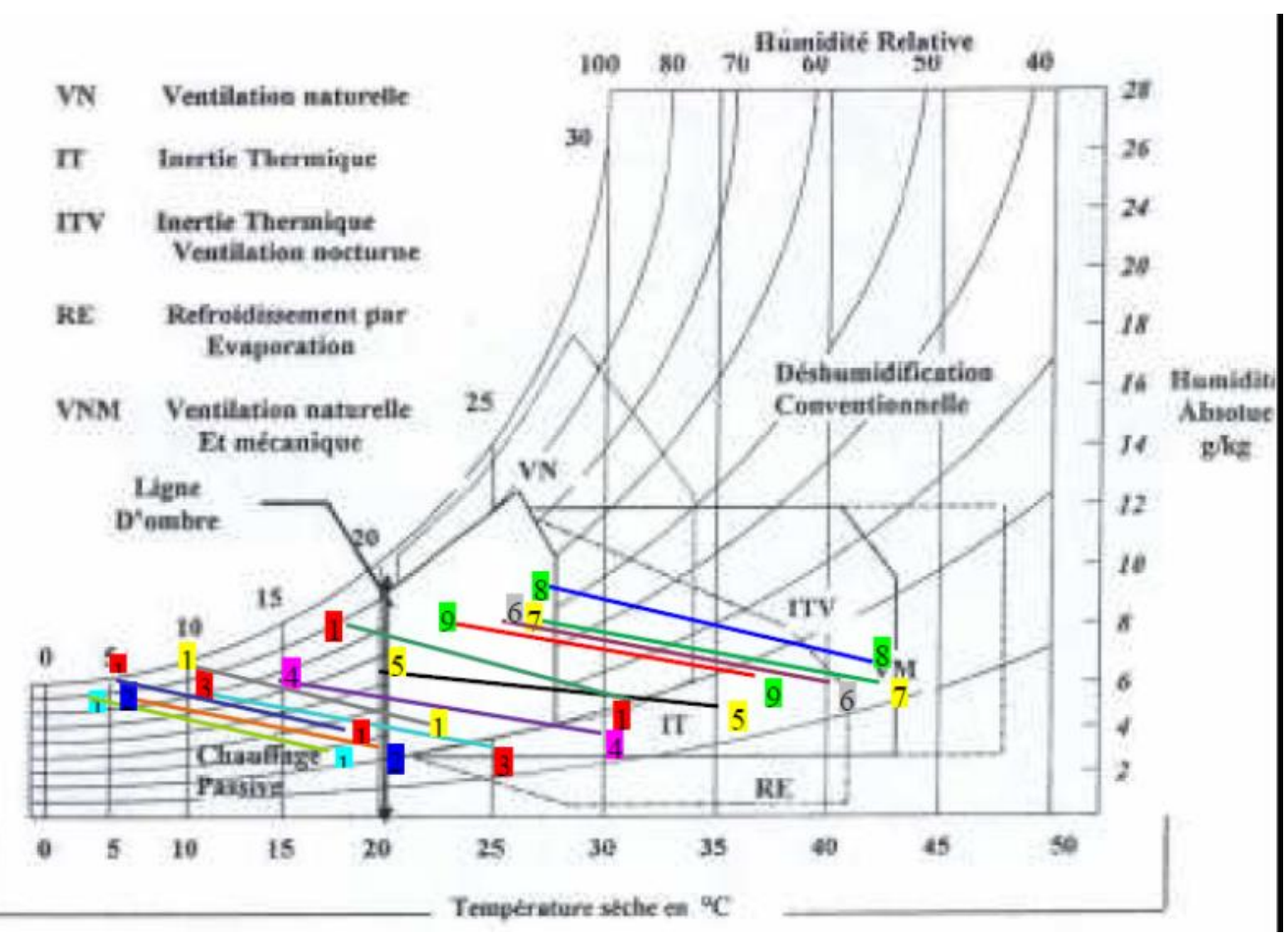

Fig. 2. GIVONI psychometric diagram with application to the climate of Hassi Messaoud [22]

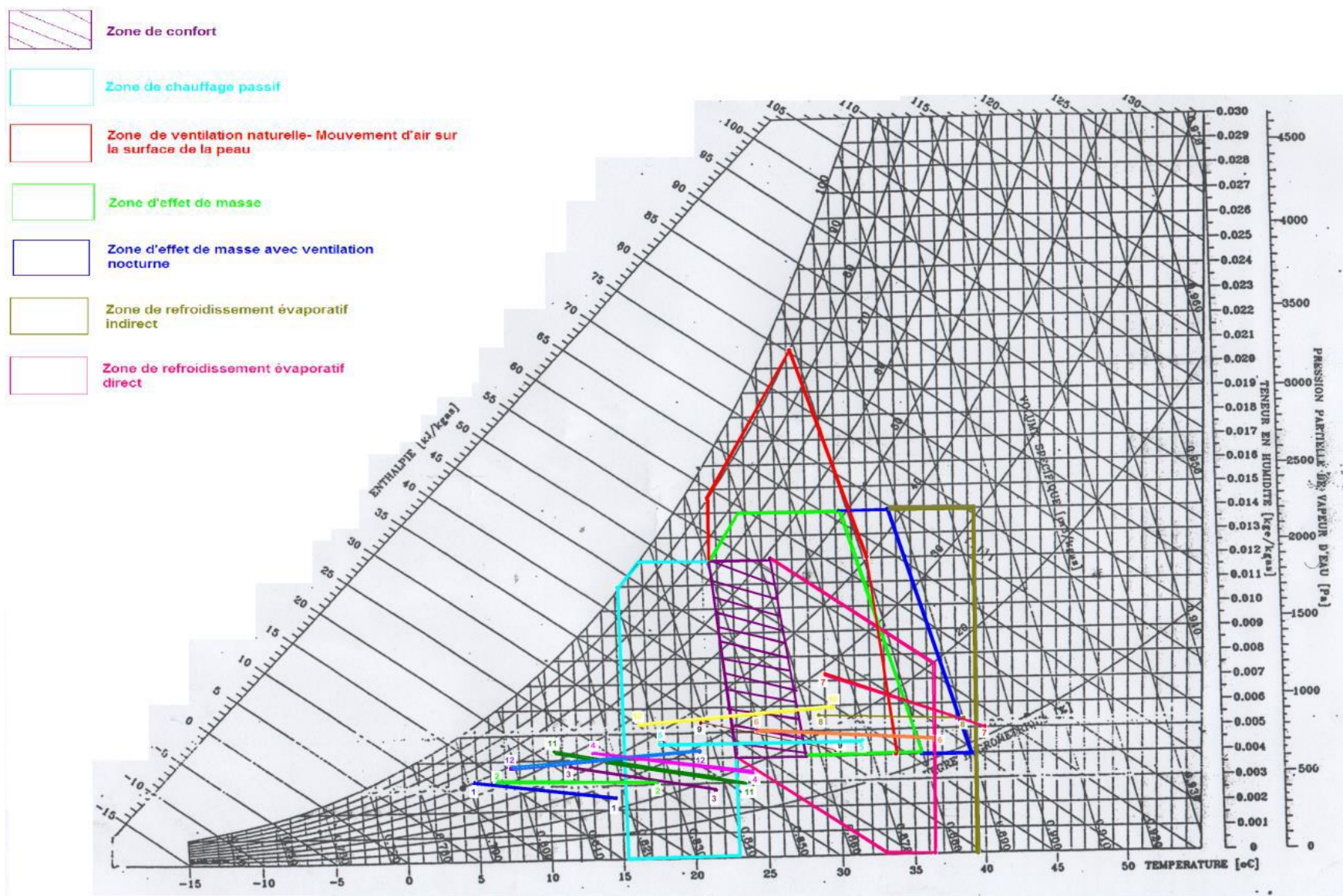

Fig. 3. GIVONI psychometric diagram with application to the climate of Bechar [16] 


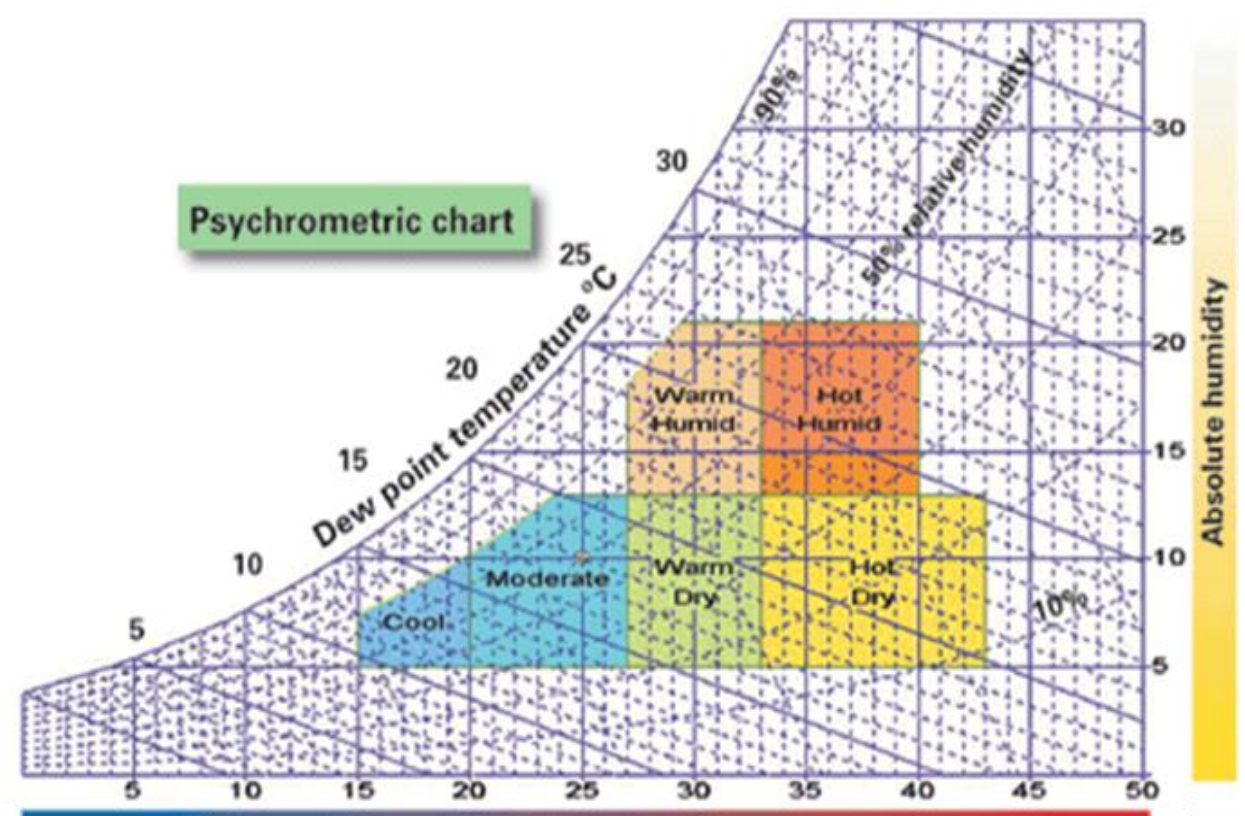

Fig. 4. Szokoly diagram for hot and dry and Mediterranean climates [16]

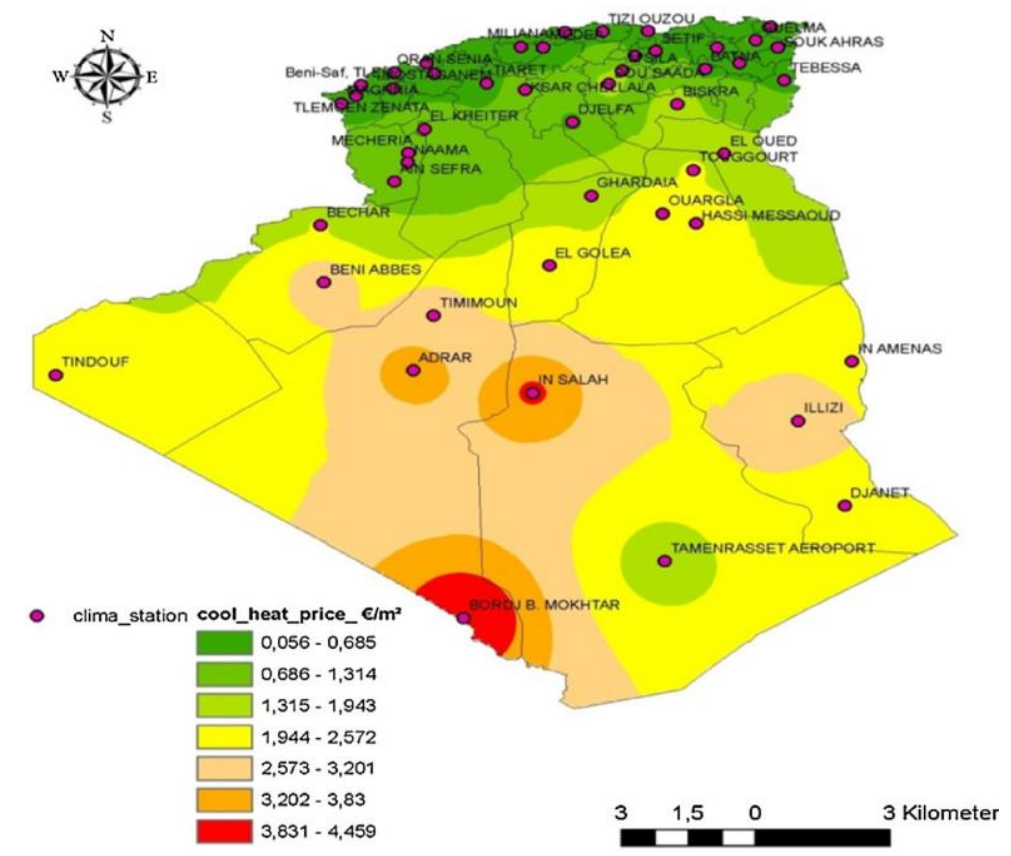

Fig. 5. Climate zones in Algeria according to energy consumption costs [19]

\section{Studied configurations}

Four configurations were selected for analysis: case A, B, and C and a reference case (Figure 6). This study analysed the four basic different configurations of natural ventilation (Figure 6). Table 1 presents the composition of the building envelope, the thickness of each material, and the heat transfer coefficient for walls and roofs. 

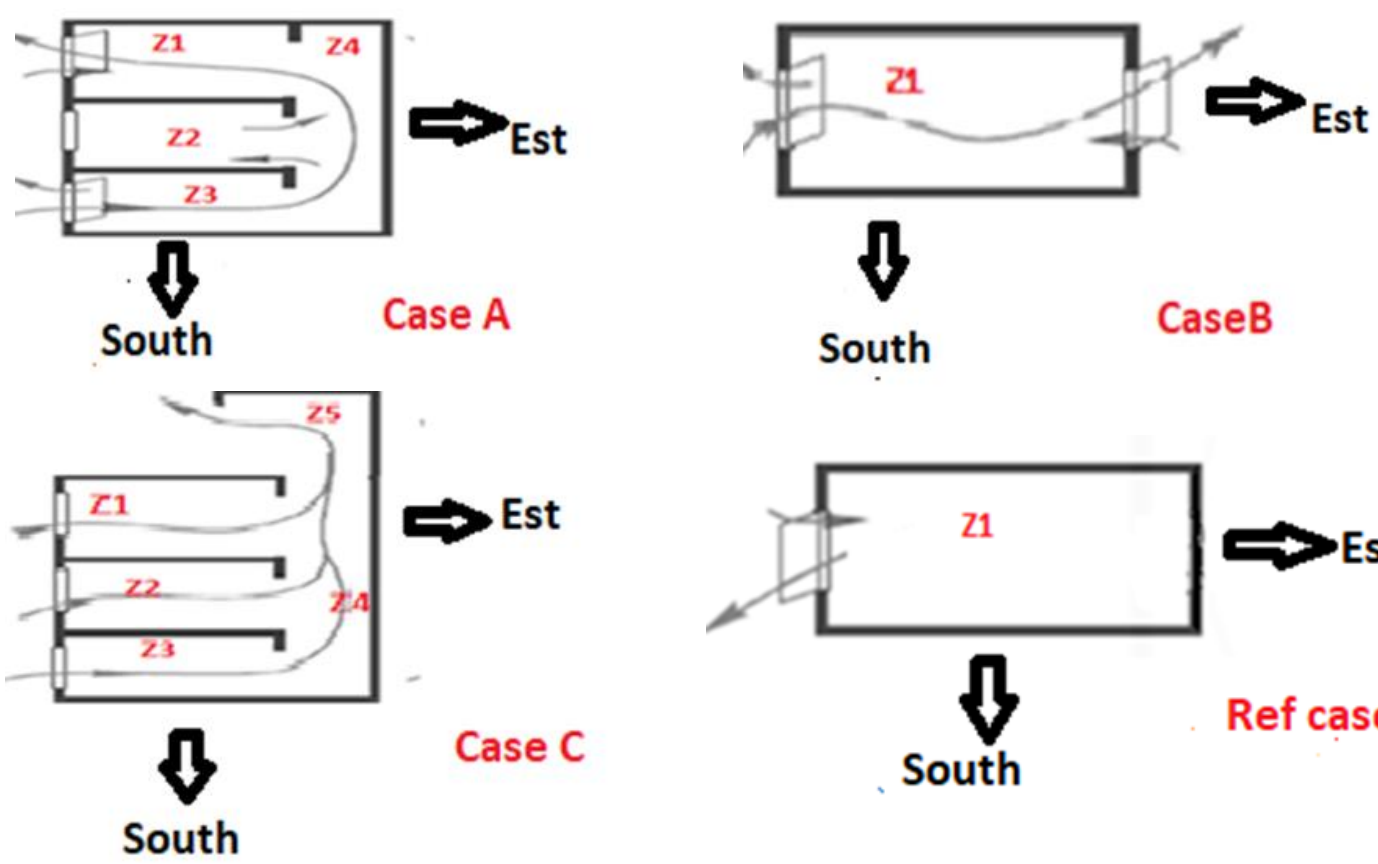

South

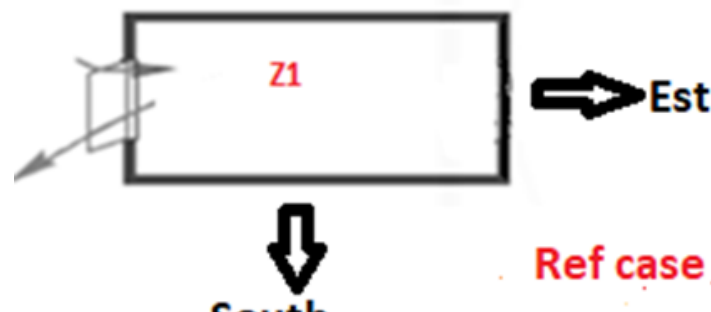

South

Fig. 6. Four configurations selected for analysis: case $A, B$, and $C$ and a reference case

Table 1

Composition of the cell envelope

\begin{tabular}{|c|c|c|c|}
\hline & Building materials & & $\mathrm{U}\left[\mathrm{W} /\left(\mathrm{m}^{2} \mathrm{~K}\right)\right]$ \\
\hline Wall & Constitution (from the inside to outside) & Thickness (cm) & \\
\hline wall outside/ & Interior plaster & 3 & 0.637 \\
\hline \multirow[t]{4}{*}{ Interior wall } & Red brick & 10 & \\
\hline & Expanded polystyrene & 3 & \\
\hline & Red brick & 15 & \\
\hline & Exterior plaster & 3 & \\
\hline \multirow[t]{4}{*}{ Roof external } & Interior plaster & 3 & 2.352 \\
\hline & Hourdi 16 & 16 & \\
\hline & Concrete & 4 & \\
\hline & Floor tile & 3 & \\
\hline \multirow[t]{4}{*}{ Floor basic } & Floor tile & 2 & 0.864 \\
\hline & Concrete & 20 & \\
\hline & Expanded polystyrene & 2 & \\
\hline & Pierre & 40 & \\
\hline \multirow{4}{*}{ floors roof } & Interior plaster & 3 & 2.352 \\
\hline & Hourdi 16 & 16 & \\
\hline & Concrete & 4 & \\
\hline & Floor tile & 3 & \\
\hline
\end{tabular}

\subsection{Reference Case (Mono one)}

The basic cell (Z1) of an area and a height of $20 \mathrm{~m}^{2}$ and $2.8 \mathrm{~m}$, respectively, has a single onedimensional window $(1.4 \times 1.2) \mathrm{m}^{2}$ facing west.

\subsection{Configurations of The Analysed Cases}

Case A: The block comprises a ground floor (Z3) and two other floors, namely Z2 and Z1; all these three areas have the same dimensions as those of the basic reference cell. Zone 1 and Zone 3 are 
provided with the same one-dimensional window $(1.4 \times 1.2) \mathrm{m}^{2}$ oriented towards the west. Each zone is connected to the stairwell $(\mathrm{Z4})$ of dimensions $(2.10 \times 9.2) \mathrm{m}^{2}$ through a door of dimension $(1 \times 2) \mathrm{m}^{2}$.

Case B: The cell comprises a single area (Z1) of $20 \mathrm{~m}^{2}$ provided with two identical windows of dimension $(1.4 \times 1.2) \mathrm{m}^{2}$ located on two opposite facades.

Case C: The block comprises a ground floor (Z3) and two other floors, namely Z2 and Z1. Each zone has the same area of $20 \mathrm{~m}^{2}$ and is provided with the same one-dimensional window of $(1.4 \times$ 1.2) $\mathrm{m}^{2}$ oriented to the west. Each zone is connected to the staircase (Z4) of dimension $(2.10 \times 9.2)$ $\mathrm{m}^{2}$ through a door of dimension $(1 \times 2) \mathrm{m}^{2}$. The building is equipped with a terrace $(\mathrm{Z5})$ that contains a large high opening of dimension $(1.5 \times 1) \mathrm{m}^{2}$ and is oriented to the west.

\section{Internal Earnings and Occupancy Strategy}

The internal inputs and used schedule of the buildings are considered similar for different zones, and the same likely occupation schedule is applied to each zone. Subsequently, each cell is assumed to house two people from 12 a.m to 7 a.m. and from 5 p.m. to 12 a.m. One person is supposed to be present between $12 \mathrm{p} . \mathrm{m}$. to $5 \mathrm{p} . \mathrm{m}$. The level of metabolic activity is 1.5 and 1 met from 8 a.m. to 11 p.m. and from 11 p.m. to 8 a.m., respectively. The thermal resistance of clothes is 0.5 clo (summer outfit). Let us assume that the relative speed of air is $0.1 \mathrm{~m} / \mathrm{s}$ [16]. Another schedule concerning the use of artificial lighting, computers, and televisions should also be considered (Table 2).

\section{Table 2}

Schedule for the use of artificial lighting, computers, and televisions

\begin{tabular}{ll}
\hline Apparatus & Time of use $(\mathrm{h})$ \\
\hline TV & $7-14$ and $17-23$ \\
computer & $10-12$ and $17-23$ \\
Lighting & $7-8$ and $18-23$ \\
\hline
\end{tabular}

\section{Night Ventilation Method}

The study of ventilation in buildings is crucial to improve the quality of the indoor environment [23] and to reduce the total energy consumption of the buildings by $60 \%$ [24]. Natural ventilation was acquired using a simple exposure type, transverse and thermal draft. Natural ventilation was created by opening building openings [25]. Configurations were characterised by two types of openings that were either in contact with the outside of the building or directly overlooked the stairwell. To test the effectiveness of the natural ventilation potential generated by each configuration according to the climate, five schedules were proposed (Table 3). The following seven climatic regions that represent all types of climatic zones in Algeria were selected.

i. Adrar, Bechar, Ilizi, Ouargla, and In-salah: hot climates from the south of Algeria

ii. Oran: a coastal climate from the north of Algeria

iii. Djelfa: a highland climate from the plateaus of Algeria 


\begin{tabular}{|c|c|c|c|c|c|c|}
\hline \multirow[t]{2}{*}{ Case } & \multirow[t]{2}{*}{ Month } & \multirow[t]{2}{*}{ Towns } & \multicolumn{2}{|c|}{ Opening on the outside } & \multicolumn{2}{|c|}{ Sashes opening into the stairwell } \\
\hline & & & Opened & Closed & Opened & Closed \\
\hline \multirow[t]{2}{*}{ V1 } & $\begin{array}{l}\text { May, September, } \\
\text { October }\end{array}$ & $\begin{array}{l}\text { Adrar, Bechar, } \\
\text { Ilizi, Ouargla,In-salah }\end{array}$ & \multirow[t]{2}{*}{-} & \multirow[t]{2}{*}{$24 \mathrm{~h}$} & \multirow[t]{2}{*}{-} & \multirow[t]{2}{*}{$24 \mathrm{~h}$} \\
\hline & Juin, juillet, aout & Oran, Djelfa & & & & \\
\hline \multirow[t]{2}{*}{ V2 } & $\begin{array}{l}\text { May, September, } \\
\text { October }\end{array}$ & $\begin{array}{l}\text { Adrar, Bechar, } \\
\text { Ilizi, Ourgla, In-salah }\end{array}$ & \multirow{2}{*}{$\begin{array}{l}7 \text { p.m. } \\
\text { to } 9 \text { a.m. } \\
(90 \%)\end{array}$} & \multirow[t]{2}{*}{-} & \multirow{2}{*}{$\begin{array}{l}7 \text { p.m. } \\
\text { to } 9 \text { a.m. } \\
(90 \%)\end{array}$} & \multirow[t]{2}{*}{-} \\
\hline & Juin, juillet aout & Oran, Djelfa & & & & \\
\hline \multirow[t]{2}{*}{ V3 } & $\begin{array}{l}\text { May, September, } \\
\text { October }\end{array}$ & $\begin{array}{l}\text { Adrar, Bechar, } \\
\text { Ilizi, Ourgla, In-salah }\end{array}$ & \multirow{2}{*}{$\begin{array}{l}7 \text { p.m. } \\
\text { to } 9 \text { a.m. } \\
(90 \%)\end{array}$} & \multirow[t]{2}{*}{-} & \multirow{2}{*}{$\begin{array}{l}\text { Opened } \\
\text { if } \\
\mathrm{T}_{\text {cage }}<\mathrm{T}_{\text {int }}\end{array}$} & \multirow[t]{2}{*}{-} \\
\hline & Juin, juillet, aout & Oran, Djelfa & & & & \\
\hline \multirow[t]{2}{*}{ V4 } & $\begin{array}{l}\text { May, September, } \\
\text { October }\end{array}$ & $\begin{array}{l}\text { Adrar, Bechar, } \\
\text { Ilizi, Ourgla, In-salah }\end{array}$ & \multirow{2}{*}{$\begin{array}{l}\text { Opened } \\
\text { if } \\
\mathrm{T}_{\text {ext }}<\mathrm{T}_{\text {int }}\end{array}$} & \multirow[t]{2}{*}{-} & $\begin{array}{l}7 \text { p.m. } \\
\text { to } 9 \text { a.m. }\end{array}$ & \multirow[t]{2}{*}{-} \\
\hline & Juin, juillet aout & Oran, Djelfa & & & $(90 \%)$ & \\
\hline \multirow[t]{2}{*}{ V5 } & $\begin{array}{l}\text { May, September, } \\
\text { October }\end{array}$ & $\begin{array}{l}\text { Adrar, Bechar, } \\
\text { Ilizi, Ourgla, In-salah }\end{array}$ & \multirow{2}{*}{$\begin{array}{l}\text { Opened } \\
\text { if } \\
\mathrm{T}_{\text {ext }}<\mathrm{T}_{\text {int }}\end{array}$} & \multirow[t]{2}{*}{-} & $\begin{array}{l}\text { Opened } \\
\text { if }\end{array}$ & \multirow[t]{2}{*}{-} \\
\hline & Juin, Juillet, aout & Oran, Djelfa & & & $\mathrm{T}_{\text {cage }}<\mathrm{T}_{\text {int }}$ & \\
\hline
\end{tabular}

Five different schedules are as follows

i. Schedule V1: all openings are closed.

ii. Schedule V2: all openings are open for night ventilation from 7 p.m. to 9 a.m.

iii. Schedule V3: the windows are open for night ventilation from 7 p.m. to 9 a.m., doors are open provided that the interior temperature of the considered area exceeds stairwell temperature ( $\left.T_{\text {int }}>T_{\text {cage }}\right)$.

iv. Schedule V4: windows are open provided that the temperature of the considered area is higher than that of the outside $\left(T_{\text {int }}>T_{\text {ext }}\right)$, and doors are open constantly during nights from 7 p.m. to 9 a.m.

v. Schedule V5: all openings are open under the following conditions: windows are open if the interior temperature of the considered zone is higher than external temperature ( $\left.T_{\text {int }}>T_{\text {ext }}\right)$, and doors are open if the internal temperature of the zone is higher than staircase temperature ( $\left.T_{\text {int }}>T_{\text {cage }}\right)$.

The ventilation potential was analysed in the summer for the coastal climate in the north of the country (Oran) and highland climate (Djelfa). However, for the climates of areas situated in the south of the country, the study was limited to the mid-season period.

\section{Numerical Simulations}

The thermal aeraulic modelling of each configuration was conducted using TRNSYS software coupled with COMIS software, and the climatic data of the selected cities was obtained through METEONORM software. Furthermore, soil temperature was determined using the simple type 77 characterise the effects of wind on building facades and roofs, were calculated on the basis of a (Cp) generator tool (Table 4) [16]. 


\begin{tabular}{|c|c|c|c|c|c|c|c|c|c|}
\hline Case & Wind direction & $0^{\circ}$ & $45^{\circ}$ & $90^{\circ}$ & $135^{\circ}$ & $180^{\circ}$ & $225^{\circ}$ & $270^{\circ}$ & $315^{\circ}$ \\
\hline \multirow[t]{3}{*}{$A$} & $\begin{array}{l}\text { Vertical openings at the } \\
\text { top }\end{array}$ & -0.65 & 0.201 & 0.109 & 0.251 & -0.498 & -0.302 & -0.205 & -0.267 \\
\hline & $\begin{array}{l}\text { Vertical openings in the } \\
\text { middle }\end{array}$ & -0.59 & 0.121 & 0.018 & 0.207 & -0.412 & -0.271 & -0.121 & -0.245 \\
\hline & $\begin{array}{l}\text { Vertical openings at the } \\
\text { bottom }\end{array}$ & -0.45 & 0.115 & 0.005 & 0.118 & -0.389 & -0.231 & -0.109 & -0.211 \\
\hline$B$ & Vertical opening & -0.62 & 0.112 & 0.003 & 0.112 & -0.471 & -0.224 & -0.105 & -0.201 \\
\hline \multirow[t]{4}{*}{$\mathrm{C}$} & $\begin{array}{l}\text { Vertical openings at the } \\
\text { top }\end{array}$ & -0.65 & 0.201 & 0.109 & 0.251 & -0.498 & -0.302 & -0.205 & -0.267 \\
\hline & $\begin{array}{l}\text { Vertical openings in the } \\
\text { middle }\end{array}$ & -0.59 & 0.121 & 0.018 & 0.207 & -0.412 & -0.271 & -0.121 & -0.245 \\
\hline & $\begin{array}{l}\text { Vertical openings at the } \\
\text { bottom }\end{array}$ & -0.45 & 0.115 & 0.005 & 0.118 & -0.389 & -0.231 & -0.109 & -0.211 \\
\hline & $\begin{array}{l}\text { High vertical chimney } \\
\text { opening }\end{array}$ & -0.67 & 0.208 & 0.111 & 0.252 & -0.499 & -0.308 & -0.206 & -0.269 \\
\hline
\end{tabular}

The values of discharge coefficients (Cd), which consider the physical effects of flow contraction and frictional forces, and the values of flow coefficients for cracks (Cs) and the exponent ( $n$ ) of air flow were calculated by referring to the studies $[16,26]$ (Table 5$)$.

Table 5

\begin{tabular}{lll}
\multicolumn{2}{l}{ Discharge coefficients (Cd) and coefficient for cracks (Cs) of vertical openings } \\
\hline Cd (discharge coefficients) & Internal doors & 0.2472 \\
& External windows & 0.6 \\
\hline Cs (coefficient for cracks) & Walls & $4.608 \times 10^{-4}$ \\
$\mathrm{~kg} / \mathrm{s} \mathrm{m} \mathrm{Pan}$ & Roof & $4.032 \times 10^{-4}$ \\
& Windows & $2.7 \times 10^{-5}$ \\
& Doors & $1.33 \times 10^{-4}$ \\
\hline
\end{tabular}

\section{Results and Discussion}

The results are presented in terms of hours of hot and cold discomfort (HTC, HTF) according to standard EN-15257. To achieve the thermal comfort of each configuration, maximum and minimum temperatures ( $T_{\max }, T_{\min }$ ) were used. Only the most valuable results according to different climates are reported here.

First, the evolution of internal temperature through the five opening schedules, namely V1, V2, V3, V4, and V5, for the three zones of case A was plotted for four days in mid-May and for three different climates: Oran (Figure 7), Djelfa (Figure 8), and Adrar (Figure 9). The results obtained with the five opening schedules were compared with $T_{\text {ext }}$ and $T_{\text {ref }}$ schedules.

According to the climate evolution of Oran (Figure 7), all temperatures representative schedules were $<30^{\circ} \mathrm{C}$ for the three zones of the building. The temperatures representative of schedule V1 for zone 1 exceeded that of the reference case. Therefore, the area of the top floor was hotter than that of the ground floor ' $\mathrm{Z3}$ ' and middle floor ' $\mathrm{Z2}$ '; the middle floor exhibited low temperature fluctuations for all opening schedules. Moreover, in zones 1 and 3, for all the opening schedules, higher temperatures were obtained compared outside temperatures and lower temperatures were obtained than the reference case. The results of V2 and V3 schedules were almost the same. Schedule V5 generated the lowest temperature among the temperature recorded for the examined schedules. The temperature of zone 1 exhibited an increase and a decrease of approximately $4^{\circ} \mathrm{C}$ and $2^{\circ} \mathrm{C}$, 
respectively, during the night and day, respectively, compared with the outside temperature. Furthermore, compared with the temperatures of the reference case, the daytime and night time temperatures of zone 1 exhibited a decrease of approximately $3^{\circ} \mathrm{C}$ and $5^{\circ} \mathrm{C}$, respectively. By contrast, in zone 3 , schedule $\mathrm{V} 5$ recorded a decrease of $2^{\circ} \mathrm{C}$ in daytime temperature compared with the outside temperature. During the night, the outside temperature recorded was $<14^{\circ} \mathrm{C}$, whereas the night ventilation presented by schedule V5 provided the temperatures of $>16^{\circ} \mathrm{C}$.

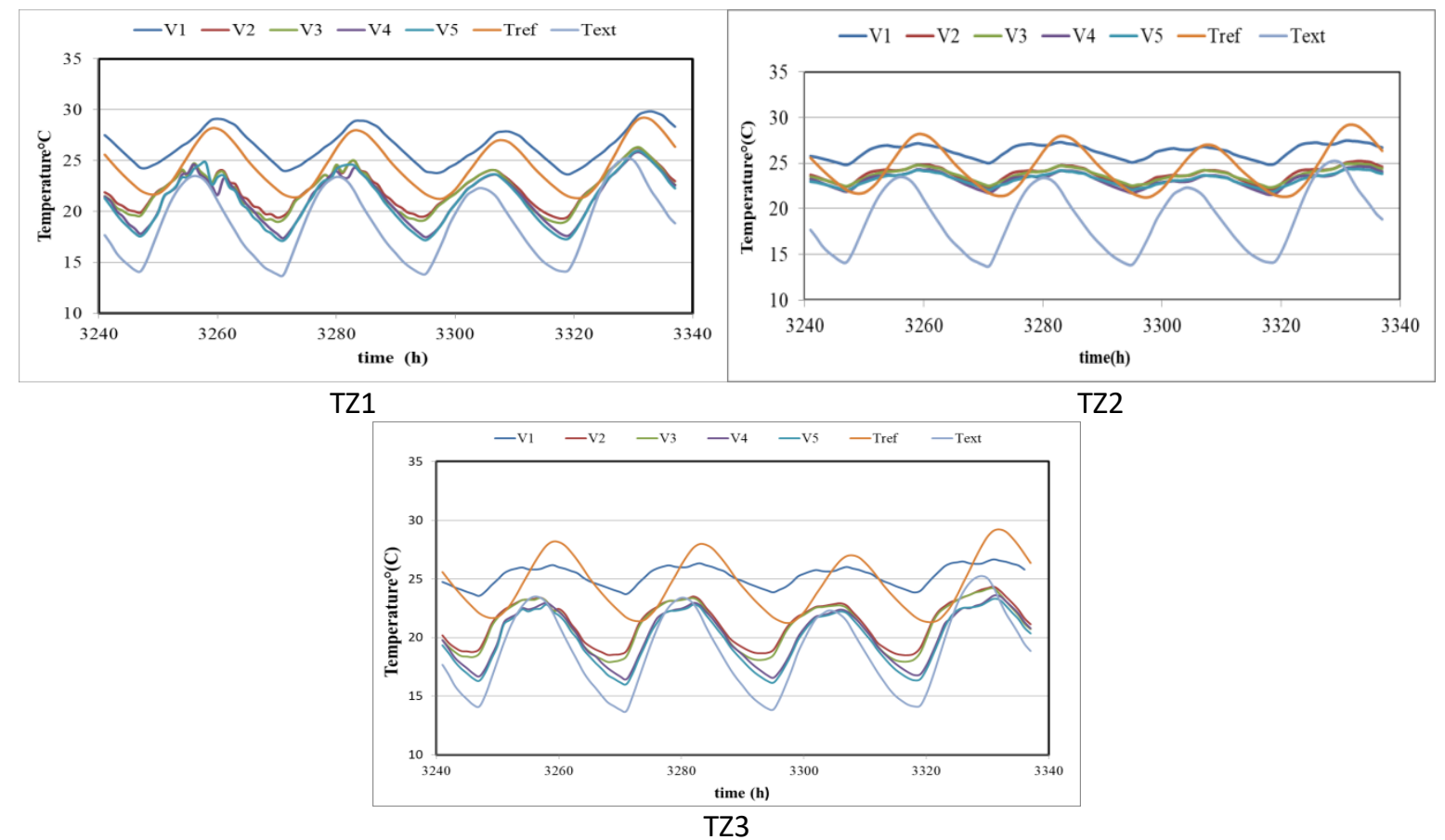

Fig. 7. Oran climate for the three studied areas: TZ1, TZ2, and TZ3 (Case A)

According to the climate evolution of Djelfa (Figure 8), the temperatures recorded for the three zones exhibited the following characteristics:

Zone 1 exhibited the highest temperatures, followed by zone 2, and zone 3 exhibited the lowest temperatures. Opening schedules presented lower temperatures than the reference case did. By contrast, V2 and V3 schedules provided almost similar results. The results of schedules V4 and V5, which presented the same appearance, were almost similar. In addition, and during the day, the temperature of schedule V 5 decreased by approximately $3^{\circ} \mathrm{C}$ compared with the schedule where all openings were closed and by $2^{\circ} \mathrm{C}$ compared with outside temperature.

With night ventilation, the temperature of approximately $17^{\circ} \mathrm{C}$ was recorded because the Djelfa climate can cause cool nights during May where outside temperature can decrease to $10^{\circ} \mathrm{C}$. The temperature difference between day and night was approximately $5^{\circ} \mathrm{C}$. In addition, during the day for schedule V5, a decrease of $2^{\circ} \mathrm{C}$ was observed compared with outside temperature and of $3^{\circ} \mathrm{C}$ compared with schedule V1. At night, the situation was different for schedule V5; an increase of nearly $3^{\circ} \mathrm{C}$ was observed compared with outside temperature and a decrease of approximately $8^{\circ} \mathrm{C}$ was observed compared with schedule V1.

Thus, the results related to the temperature levels recorded during the day and night demonstrated the effectiveness of natural ventilation for Oran and Djelfa climates for the period of mid-May. 


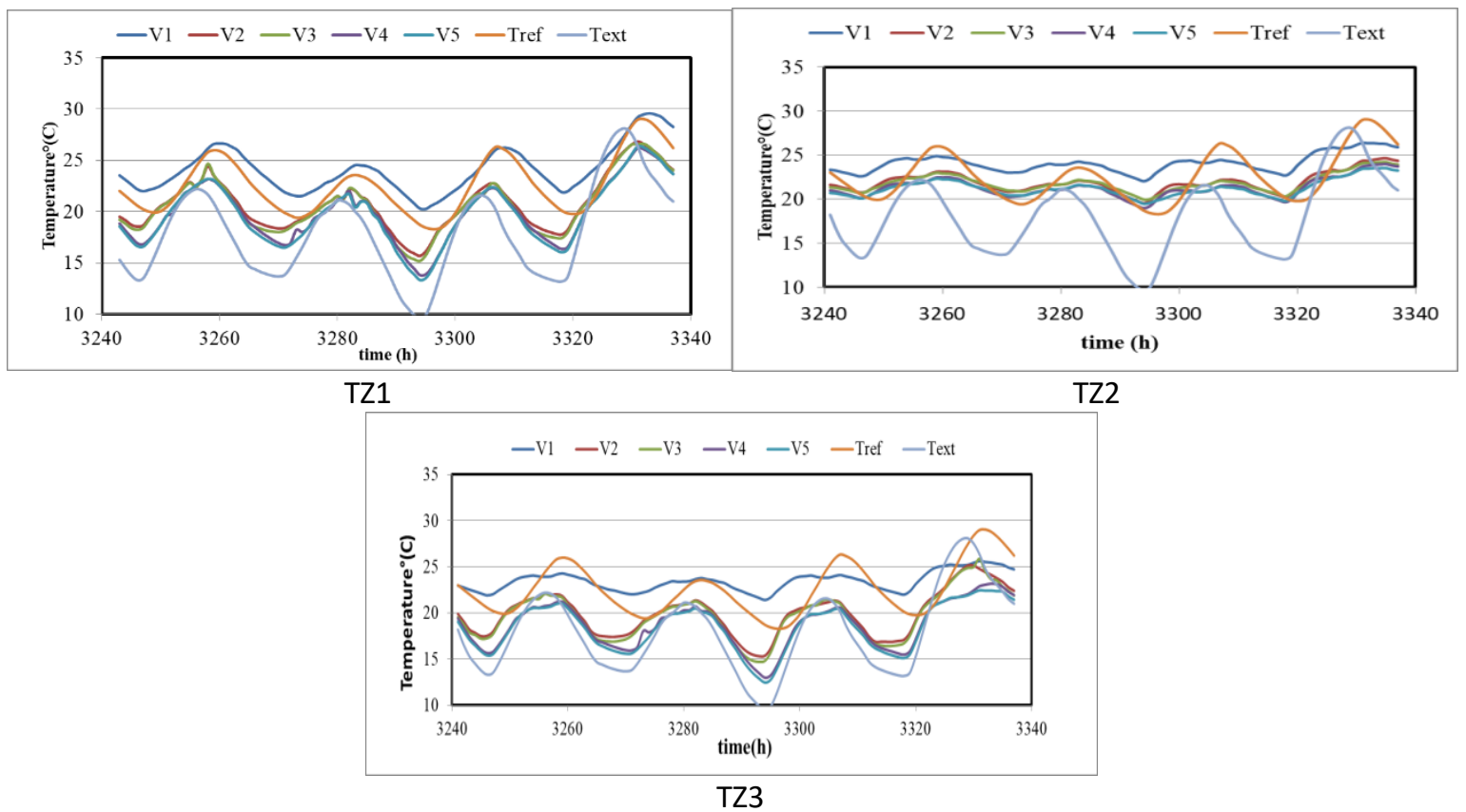

Fig. 8. Djelfa climate for the three studied areas: TZ1, TZ2, and TZ3 (Case A)

For the Adrar climate, the temperatures recorded were $>30^{\circ} \mathrm{C}$, which is the temperature limit for summer comfort (EN 15257) (Figure 9). The temperature of $Z 2$ oscillated in an interval of $2.5^{\circ} \mathrm{C}$, and that of the top $\mathrm{Z} 1$ the ground $\mathrm{Z3}$ floors oscillated in an interval of $13^{\circ} \mathrm{C}$ and $8^{\circ} \mathrm{C}$, respectively. By contrast, the natural night-time ventilation was not performant in $\mathrm{Z} 2$ because the calculated deviation related to outside temperature during the night was $9^{\circ} \mathrm{C}$, especially at approximately 4 a.m. when outside temperature reached its maximum in May.

The results of Z3 showed that the temperatures of $\mathrm{V} 2$ and $\mathrm{V} 3$ variants exceeded that of $\mathrm{V} 1$ variant during an estimated period time of $4 \mathrm{~h}$. Consequently, natural ventilation cannot be considered a technique that can provide a solution to control thermal comfort even during the mid-season in regions characterised by a hot and arid climate.
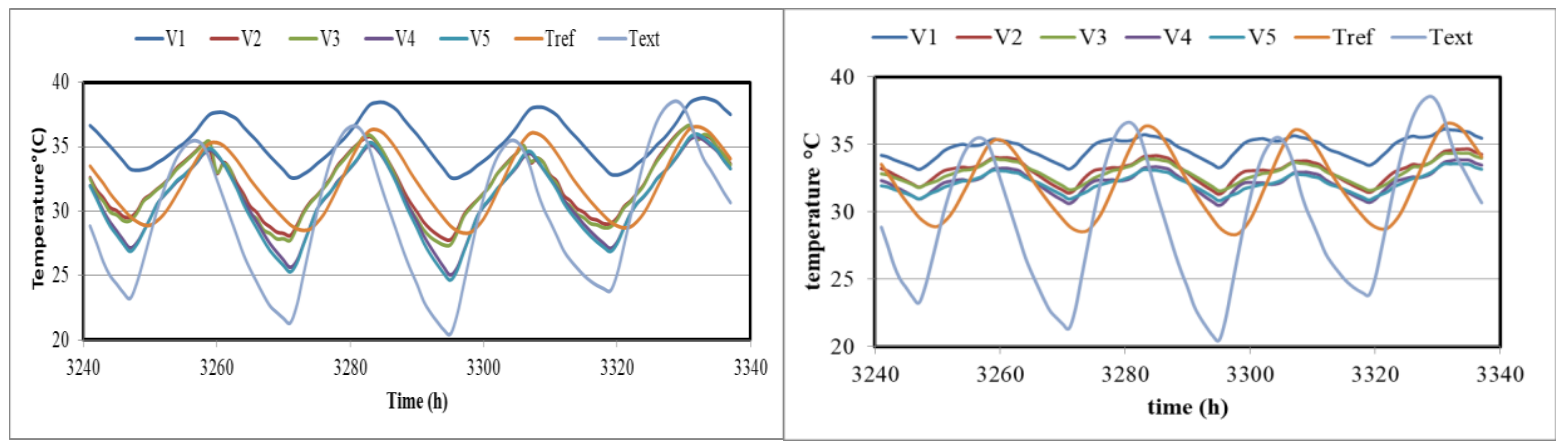

TZ1 TZ2

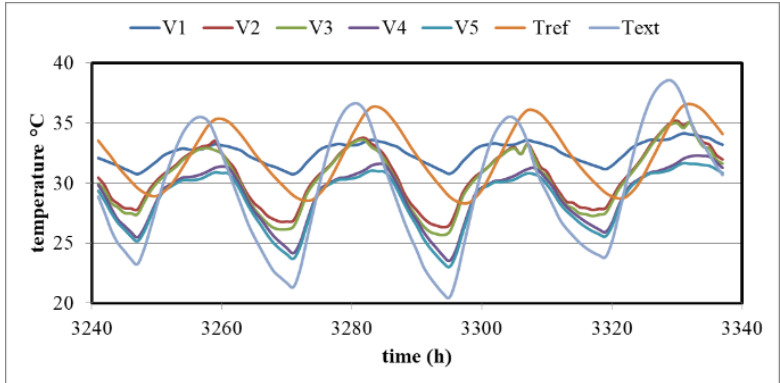

TZ3

Fig. 9. Adrar climate for the three studied areas: TZ1, TZ2, and TZ3 (Case A) 
Figure 7 to 9 confirm the reliability of natural ventilation of zone 3 that can be explained by the air flow level. The level of the air flow introduced in zone 3 was the highest, followed by that of zone 1 , and that of zone 2 was the lowest (Figure 10). Therefore, the thermal behaviour was the consequence of the position of each zone in the building. Zone 1 is in the direct contact with the roof, the part which is the most exposed to direct and diffuse solar rays during the day [12]. By contrast, the horizontal surface receives more solar rays than other surfaces irrespective of seasons. Moreover, zone 3, located on the ground floor, has the ceiling protected by zone $\mathrm{Z} 2$ and benefits from the direct contact with the ground. Even with the windows closed, the rate of air infiltration in this area is relatively high.

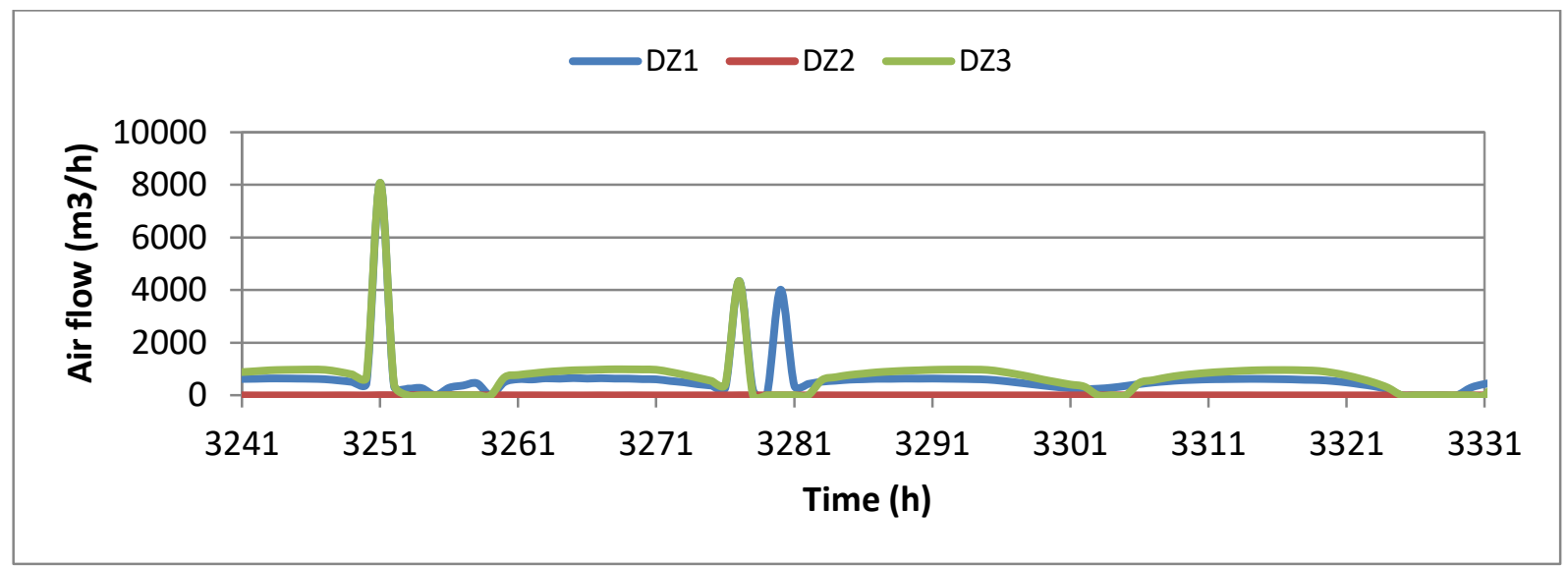

Fig. 10. Adrar climate for the three studied areas: DZ1, DZ2, and DZ3 (Case C)

Figure 11 shows the effect of the large opening height of case $C$ on temperature variations in zone 1 in mid-May for the Adrar climate caused by night ventilation (V2). The results were compared with the temperature of the reference case. First, a superposition of curves for different heights was observed. The recorded temperatures increased by $1^{\circ} \mathrm{C}$ during days and decreased by $2^{\circ} \mathrm{C}$ during nights. The temperature related to the height of $2.5 \mathrm{~m}$ decreased to a recorded level of $33^{\circ} \mathrm{C}$ during the day, for approximately $2 \mathrm{~h}$ (Figure 11). Moreover, the influence of the height of large openings during the night in zone 1 was considerable.

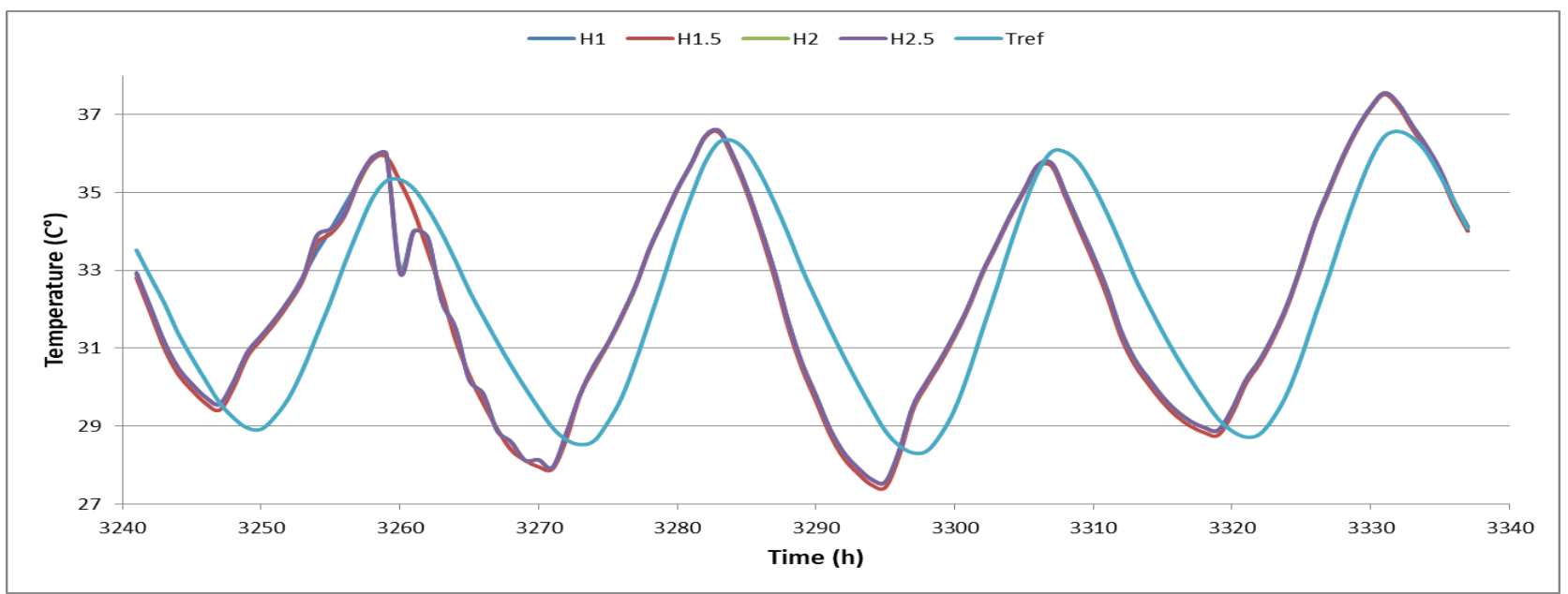

Fig. 11. Evolution of night temperature for different values of the height of large high opening for May (Adrar) 
The thermal behaviour of the studied areas should be analysed by identifying the most favourable ventilation case by examining the graphic representation of discomfort hours. Thus, to better understand the thermal behaviour of each schedule, the results were analysed in terms of hot and cold discomfort hours according to EN15257 standard. Discomfort hours corresponding to the time, during which temperature is outside the comfort zone, were calculated during the entire mid-season period for hot climate cities and during the summer for the remaining studied cities.

Figure 12 to 16 present the plots of the evolution of hot and cold discomfort hours and the maximum and minimum temperatures recorded for each proposed schedule of the three selected configurations for four different climate cities: Oran, Adrar, Djelfa, Bechar and Ouargla. The analysis focused only on the results of Z1 that is considered the hottest area.

Irrespective of the climate, schedule V5 represents the best performing schedule due to the levels of HTF and HTC recorded on the histograms. Subsequent analysis only focused on V5 schedule.

According to the results of Oran city, case B displayed almost zero HTF level, and case A was better than case $C$ (Figure 12). Compared with the level of the reference case, the HTC level of cases $A$ and $\mathrm{C}$ decreased to $78.34 \%$ and $73.94 \%$, respectively. A slight increase of $1^{\circ} \mathrm{C}$ in the maximum temperature for case $\mathrm{C}$ was observed compared with that for case $\mathrm{A}$. Moreover, case $\mathrm{A}$ presented the most favourable situation. Because the $T_{\max }$ level varied between $35^{\circ} \mathrm{C}$ and $40^{\circ} \mathrm{C}$ for all the studied cases, the selected opening method was inadequate to reduce temperature below $30^{\circ} \mathrm{C}$.

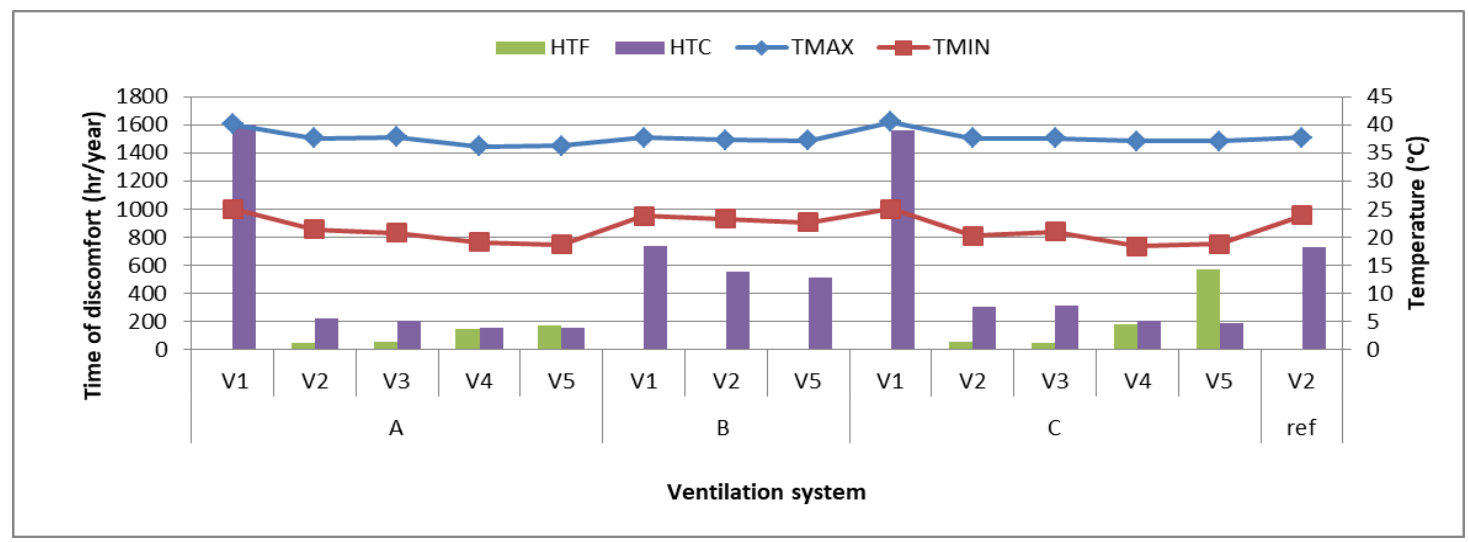

Fig. 12. Evolution of discomfort hours and maximum and minimum temperatures with time for the climate of Oran

For the Adrar city, the climate is characterised by almost zero HTF level and a HTC level that is considerably higher than the other climates in the country (Figure 13). Moreover, the results showed an HTC increase rate of $19.22 \%$ for case A compared with the reference case. However, an HTC decrease of $13.31 \%$ was observed for case $C$ compared with the reference case. Consequently, case $\mathrm{C}$ was the most favourable situation. Although $\mathrm{T}_{\max }$ varied between. $43^{\circ} \mathrm{C}$ and $46^{\circ} \mathrm{C}, \mathrm{T}_{\max }$ remained considerably higher than of the reference case. By contrast, $T_{\min }$ was more stable and varied between $19^{\circ} \mathrm{C}$ and $20^{\circ} \mathrm{C}$.

This result highlighted the arid nature of the Adrar climate even in the mid-season. Although case $\mathrm{C}$ is the most favourable situation, openings for this climate should be used substantial carefully to maintain thermal comfort. 


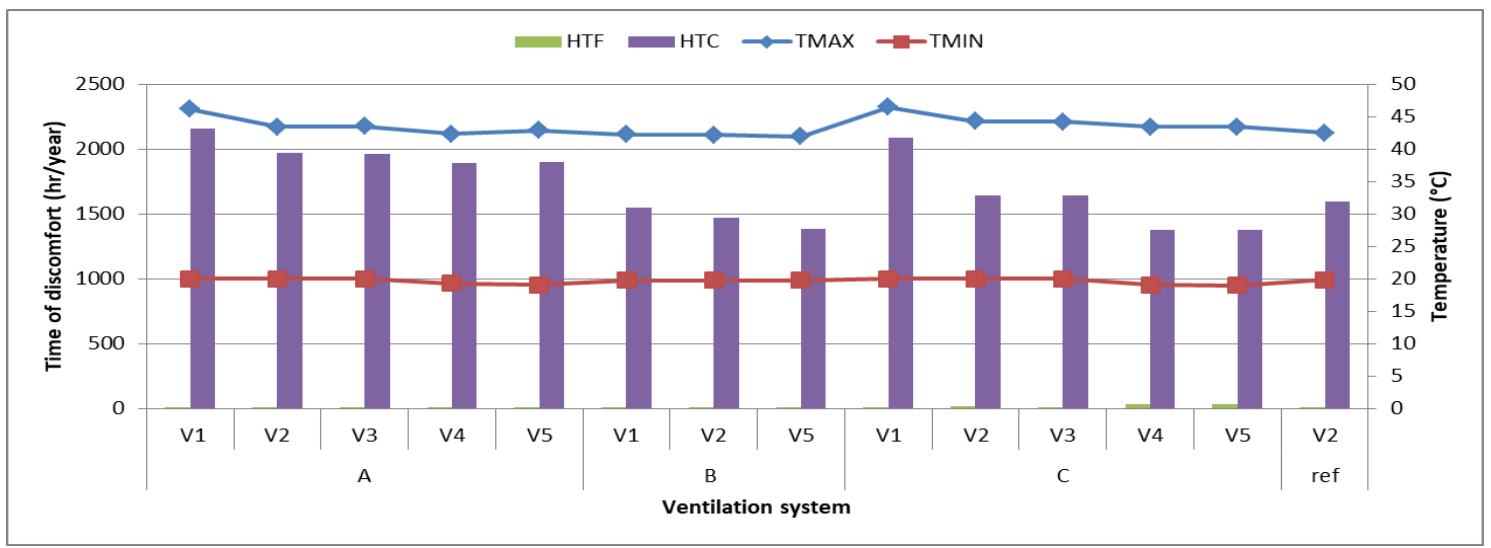

Fig. 13. Evolution of discomfort hours and maximum and minimum temperatures with time for the climate of Adrar

For the climate of Djelfa, similar to the other cities, the HTC level considerably exceeded the HTF level that appeared significantly low (Figure 14). The $T_{\min }$ of case $A$ was approximately $16^{\circ} \mathrm{C}$ with a decrease rate of $6^{\circ} \mathrm{C}$ compared with the reference case, and $T_{\max }$ oscillated around $40^{\circ} \mathrm{C}$. Moreover, the values of $\mathrm{HTC}$ and HTF for case A were at nearly the same level as for case $\mathrm{C}$. In addition, for case $B$, almost zero HTF level with an HTC level higher than that of the other cases was observed. Despite this, we opted for case A because high opening (case $\mathrm{C}$ ) construction causes additional costs.

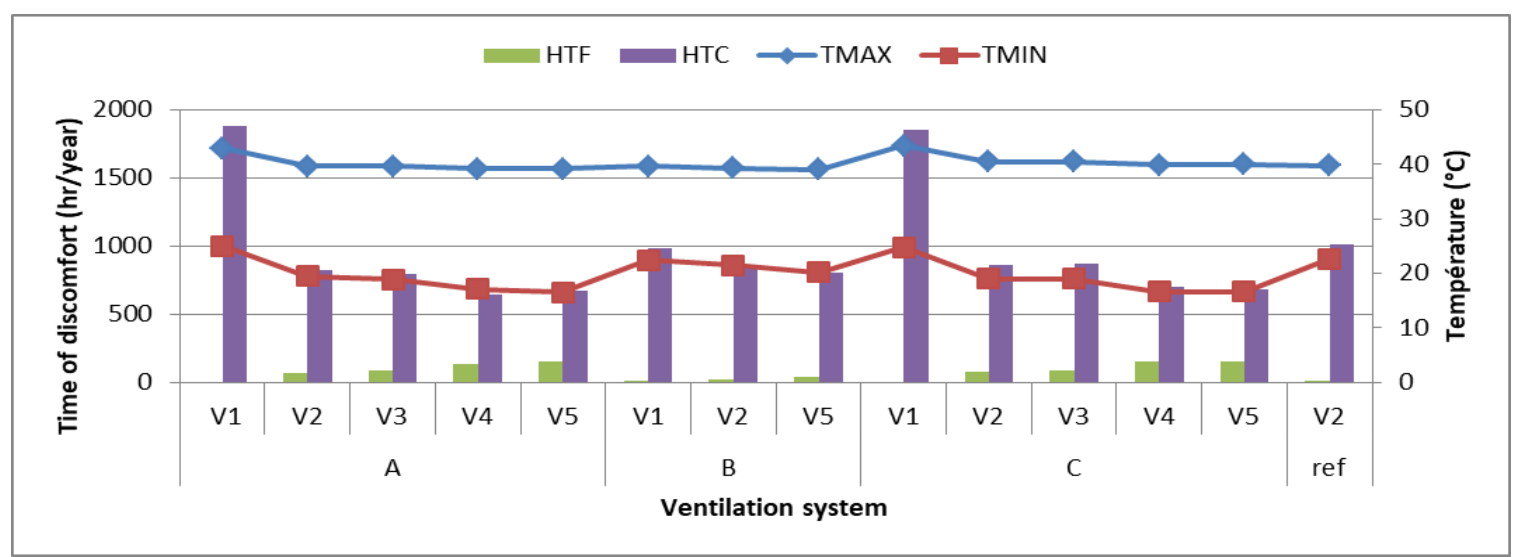

Fig. 14. Evolution of discomfort hours and maximum and minimum temperatures with time for the climate of Djelfa

The Bechar climate is characterised by a high HTF level compared with the levels observed in other climates (Figure 15). Similar to other climates, the HTC level considerably exceeded the HTF level. Furthermore, in cases $A$ and $\mathrm{C}$, a substantially small Tmin of approximately $13^{\circ} \mathrm{C}$ was recorded with a decrease rate of nearly $5^{\circ} \mathrm{C}$ compared with the reference case. By contrast, for all the analysed cases, the Tmax level did not decrease below that of the reference case.

Consequently, case A was the most favourable situation because it generated a lower HTC level than case $\mathrm{C}$ did. Moreover, the natural ventilation should be used with caution in moderate climate cities because during the mid-season period, optimal HTF and HTC values require judicious control of the air flow level induced by opening windows. 


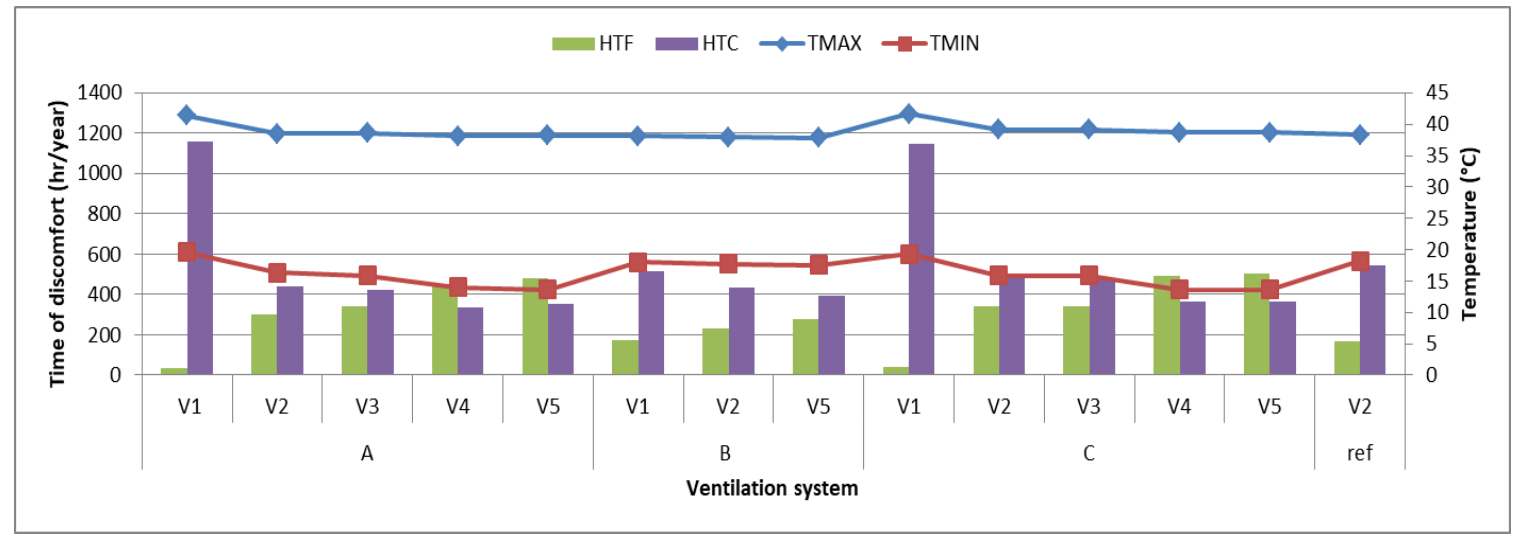

Fig. 15. Evolution of discomfort hours and maximum and minimum temperatures with time for the climate of Bechar

The results of the climate of the Ouargla city are quite similar to those of other hot climates. The HTC level was considerably higher than the HTF level, and the maximum temperature exhibited small fluctuations (Figure 16). Thus, the three cases generated maximum temperatures above $40^{\circ} \mathrm{C}$ that exceeded reference case temperature. Although a difference of $1^{\circ} \mathrm{C}$ in $T_{\max }$ values between cases $\mathrm{A}$ and $C$ was recorded, the difference in the $T_{\min }$ values between cases $A$ and $C$ and the reference case was $2^{\circ} \mathrm{C}$. The decrease rate of the $\mathrm{HTC}$ level for cases $\mathrm{A}$ and $\mathrm{C}$, compared with the rate of the refence case, was $21.92 \%$ and $20.03 \%$, respectively. In addition, case B exhibited the highest HTC level among all cases, and $T_{\min }$ remained almost stable compared with the reference case. Consequently, case $A$ was the most favourable situation.

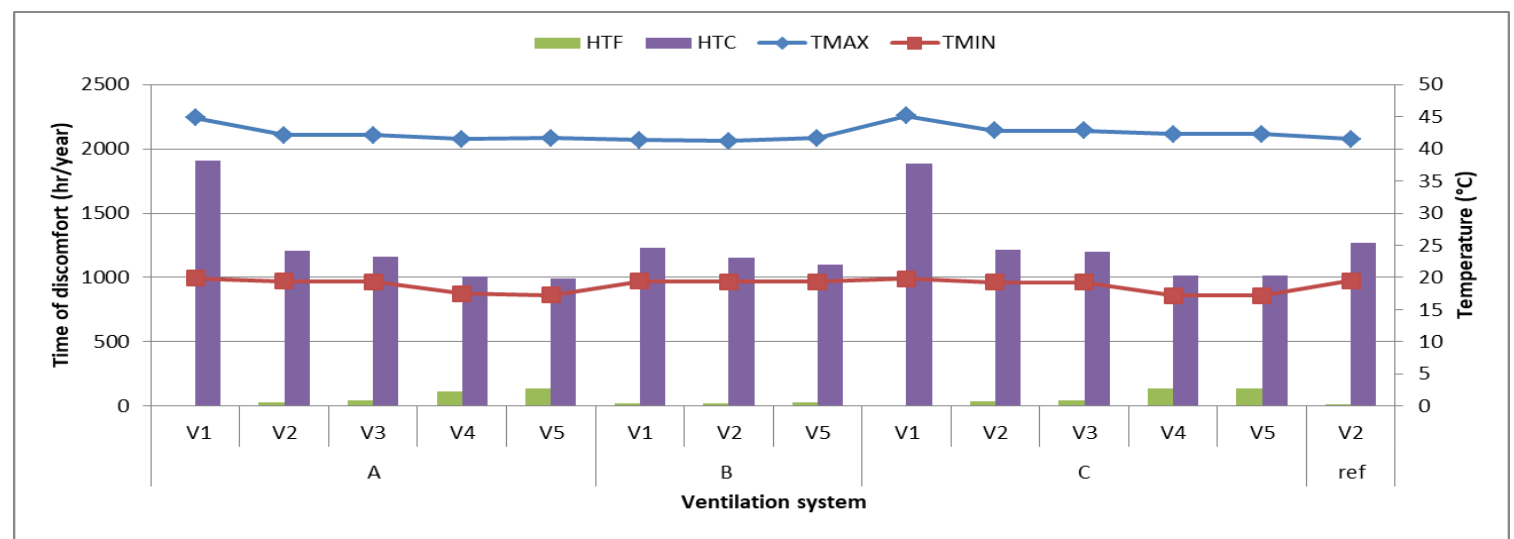

Fig. 16. Evolution of discomfort hours and maximum and minimum temperatures with time for the climate of Ouargla

\section{Conclusions}

This study tested the efficiency of natural ventilation for the thermal comfort of occupants by applying different configurations in various climates in Algeria. Irrespective of the ventilation schedule, zone 3 benefits more from natural ventilation. Moreover, zone 1 remains the hottest region due to the high number of hot discomfort hours. The fifth schedule (V5) provides the best results among all the opening schedules proposed, especially in the regions from littoral and highlands. Even with the use of the top opening (case $\mathrm{C}$ ), no improvement was observed in any selected climate. Furthermore, maximum temperatures exceeded the $30^{\circ} \mathrm{C}$ threshold and lie in an interval of $43^{\circ} \mathrm{C}-44^{\circ} \mathrm{C}, 35^{\circ} \mathrm{C}-40^{\circ} \mathrm{C}, 40^{\circ} \mathrm{C}-45^{\circ} \mathrm{C}$, and $38^{\circ} \mathrm{C}-44^{\circ} \mathrm{C}$ in Adrar, Oran, Djelfa, and Bechar, respectively. Minimum temperatures decreased to $13^{\circ} \mathrm{C}, 10^{\circ} \mathrm{C}$, and $20^{\circ} \mathrm{C}$ in Bechar, Djelfa, and Adrar, 
respectively. In addition, natural ventilation remains an efficient and costless method in littoral and highland regions provided that ventilation is carefully checked. By contrast, natural ventilation is difficult to apply in the regions characterised by extreme climatic conditions even in mid-season. The overheating of the interior environment of buildings can occur, and direct natural ventilation becomes unnecessary under this condition. To achieve recommended comfort temperature levels, alternatives must be found by coupling natural ventilation with other passive cooling systems.

\section{Acknowledgment}

This study was supported by the Directorate General for Scientific Research and Technological Development DG-RSDT.

\section{References}

[1] Evola, Gianpiero, and Viktor Popov. "Computational analysis of wind driven natural ventilation in buildings." Energy and buildings 38, no. 5 (2006): 491-501. https://doi.org/10.1016/i.enbuild.2005.08.008

[2] Santamouris, Mat. "Cooling the buildings-past, present and future." Energy and Buildings 128 (2016): 617-638. https://doi.org/10.1016/i.enbuild.2016.07.034

[3] Rinaldi, Alessandro, Michele Roccotelli, Agostino Marcello Mangini, Maria Pia Fanti, and Francesco lannone. "Natural ventilation for passive cooling by means of optimized control logics." Procedia engineering 180 (2017): 841-850. https://doi.org/10.1016/i.proeng.2017.04.245

[4] SAIFI, Nadia, and Noureddine SETTOU. "Contribution A La Conception Des Bâtiments A Faible Consommation D’énergie Dans Les Zones Arides." PhD diss., 2015.

[5] Alvarado, Jorge L., Wilson Terrell Jr, and Michael D. Johnson. "Passive cooling systems for cement-based roofs." Building and Environment 44, no. 9 (2009): 1869-1875. https://doi.org/10.1016/j.buildenv.2008.12.012

[6] Kee, Tristan Yeo Eng, Chong Kok Hing, Basil Wong Tong Liong, Victor Bong Nee Shin, Lee Man, and Christopher Jantai Anak Boniface Djun. "Alternative Design of Air Ventilation in Passenger Lift for Thermal Comfort." CFD Letters 12 no. 1 (2020): 37-47.

[7] Porras-Amores, César, Fernando R. Mazarrón, Ignacio Cañas, and Paola Villoría Sáez. "Natural ventilation analysis in an underground construction: CFD simulation and experimental validation." Tunnelling and Underground Space Technology 90 (2019): 162-173. https://doi.org/10.1016/j.tust.2019.04.023

[8] Guo, Weihong, Xiao Liu, and Xu Yuan. "Study on natural ventilation design optimization based on CFD simulation for green buildings." Procedia Engineering 121 (2015): 573-581. https://doi.org/10.1016/j.proeng.2015.08.1036

[9] Liu, Sumei, Wuxuan Pan, Qing Cao, Zhengwei Long, Yi Jiang, and Qingyan Chen. "CFD simulations of natural cross ventilation through an apartment with modified hourly wind information from a meteorological station." Energy and Buildings 195 (2019): 16-25. https://doi.org/10.1016/i.enbuild.2019.04.043

[10] Omrani, Sara, Veronica Garcia-Hansen, Bianca Capra, and Robin Drogemuller. "Natural ventilation in multi-storey buildings: Design process and review of evaluation tools." Building and Environment 116 (2017): $182-194$. https://doi.org/10.1016/i.buildenv.2017.02.012

[11] Zaki, Ahmad, Peter Richards, and Rajnish Sharma. "Analysis of airflow inside a two-sided wind catcher building." Journal of Wind Engineering and Industrial Aerodynamics 190 (2019): 71-82. https://doi.org/10.1016/i.jweia.2019.04.007

[12] Ferroukhi, Mohammed Yacine. "Modélisation des transferts thermo-hydro-aérauliques dans les enveloppes de bâtiments: Evaluation des désordres causés par l'humidité." PhD diss., 2015.

[13] Kyritsi, Eirini, and Aimilios Michael. "An assessment of the impact of natural ventilation strategies and window opening patterns in office buildings in the mediterranean basin." Building and Environment 175 (2020): 106384. https://doi.org/10.1016/i.buildenv.2019.106384

[14] Feng, Wei, Qianning Zhang, Hui Ji, Ran Wang, Nan Zhou, Qing Ye, Bin Hao, Yutong Li, Duo Luo, and Stephen Siu Yu Lau. "A review of net zero energy buildings in hot and humid climates: Experience learned from 34 case study buildings." Renewable and Sustainable Energy Reviews $114 \quad 109303$. https://doi.org/10.1016/i.rser.2019.109303

[15] Castillo, J. A., and Guadalupe Huelsz. "A methodology to evaluate the indoor natural ventilation in hot climates: $\begin{array}{llllll}\text { Heat Balance Index." Building and } & \text { (2017): }\end{array}$ https://doi.org/10.1016/i.buildenv.2016.12.027

[16] FEZZIOUI, Naima. "Analyse et caractérisation du bilan d'énergie d'un habitat traditionnel (region sud ouest)." PhD diss., Université de Béchar-Mohamed Tahri. 
[17] BELAKEHAL, Azeddine. "Etude des aspects qualitatifs de l'eclairage naturel dans les espaces architecturaux: Cas des milieux arides à climat chaud et sec." (2006).

[18] Hamdani, M., S. M. A. Bekkouche, T. Benouaz, Rafik Belarbi, and M. K. Cherier. "The Study Natural Ventilation by Using Buildings Windows: Case Study in a Hot Dry Climate, Ghardaïa, Algeria." Energy Procedia 139 (2017): 475480. https://doi.org/10.1016/i.egypro.2017.11.240

[19] Ghedamsi, Rébha, Noureddine Settou, Abderrahmane Gouareh, Adem Khamouli, Nadia Saifi, Bakhta Recioui, and Boubekker Dokkar. "Modeling and forecasting energy consumption for residential buildings in Algeria using bottom-up approach." Energy and Buildings 121 (2016): 309-317. https://doi.org/10.1016/i.enbuild.2015.12.030

[20] Fezzioui, Naïma, Belkacem Draoui, and Claude-Alain Roulet. "Etude du comportement aéraulique des maisons à ouverture zénithale." In 1st International Seminar on the Apport of the Simulation in Technological Innovation, no. CONF. 2017.

[21] Osman, Mobark M., and Harun Sevinc. "Adaptation of climate-responsive building design strategies and resilience to climate change in the hot/arid region of Khartoum, Sudan." Sustainable Cities and Society 47 (2019): 101429. https://doi.org/10.1016/j.scs.2019.101429

[22] Djouimaa, Ahmed. "Réalisation et vérification de la performance thermique d'une tour à vent pour un rafraichissement passif dans les régions chaudes et arides. Cas de Hassi Messaoud." (2017). https://doi.org/10.1016/i.ast.2012.02.006

[23] Hatif, Ihab Hasan, Azian Hariri, and Ahmad Fu'ad Idris. "CFD Analysis on Effect of Air Inlet and Outlet Location on Air Distribution and Thermal Comfort in Small Office." CFD Letters 12 no. 3 (2020): 66-77. https://doi.org/10.37934/cfdl.12.3.6677

[24] Fohimi, Nor Azirah Mohd, Muhammad Hanif Asror, Rosniza Rabilah, Mohd Mahadzir, Mohd Fauzi Ismail Mohammud, and Farid Nasir Ani. "CFD Simulation on Ventilation of an Indoor Atrium Space." CFD Letters 12 no. 5 (2020): 52-59. https://doi.org/10.37934/cfdl.12.5.5259

[25] Sacht, Helenice, Luis Bragança, Manuela Almeida, and Rosana Caram. "Study of natural ventilation in wind tunnels and influence of the position of ventilation modules and types of grids on a modular façade system." Energy Procedia 96 (2016): 953-964. https://doi.org/10.1016/i.egypro.2016.09.173

[26] Flory-Celini, Caroline. "Modélisation et positionnement de solutions bioclimatiques dans le bâtiment résidentiel existant." PhD, Université Claude Bernard Lyon 1 (2008). 